Томислав Ж. ЈОВАНОВИЋ ${ }^{*}$

Универзитет у Београду

Филолошки факултет

Катедра за српску књижевност са

јужнословенским књижевностима

\title{
ПРОСКИНИТАРИОН И СРПСКА ПУТОПИСНА ПРОЗА ПОСВЕЋЕНА СВЕТОЈ ЗЕМЉИ
}

\begin{abstract}
Водичи по Светој земљи, или проскинитариони, представљали су током читавог средњег века, па све до новијих времена, важна и неопходна пратећа упутства путницима који су долазили у те просторе, а пре свега на поклоњење Христовом гробу. Њихови детаљни описи храмова са удаљеностима од Христовог гроба служили су поклоницима да се боље снађу доласком у света места. Својом исцрпношћу оставили су дубоког трага на путописна дела српских поклоника, нарочито у деловима у којима се описује Света земља. Сачувала су се и нека изразито путописна дела у старој српској књижевности. Она се одликују личном доживљеношћу и наративном динамиком, каква прати жанр путописа.

Кључне речи: проскинитарион, Света земља, српска путописна књижевност.
\end{abstract}

Појам Свете земље подразумева широке просторе Блиског истока на којима су се одвијала збивања обухваћена Старим и Новим заветом. На њему се укрштају три религијска тока потекла из јудаизма, хришћанства и мухамеданства. Јерусалим као средиште судбоносних збивања у настанку хришћанства постао је веома рано место у коме су се окупљали поклоници са широких простора Европе, делова Азије и Африке. Свакако су приликом поклоњења бројним светињама у самом граду и још више по ближој и даљој околини постојали локални водичи који су упућивали поклонике и помагали им да се што боље снађу. Поред таквог непосредног и живог пружања помоћи у сналажењу, временом се указала потреба за писаним водичем који је требало не само да олакша оријентисање по Светој земљи него и да је довољно предочи поклоницима док се још припремају за полазак на далеки пут. Тако је за потребе боље обавештености, поузданијег, тачнијег сналажења по Светој земљи уз шира сазнања о храмовима и подсећање на библијска збивања која су се одвијала

*tomjovan1@gmail.com 
у тим просторима настао водич за поклонике на грчком језику назван проскинита-

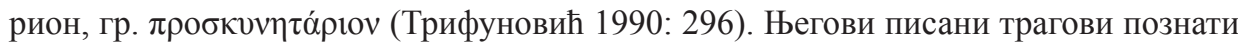
су релативно рано и потичу још из VII века. Он је потом превођен на друге језике, а између осталих и на словенски.

Проскинитариони доносе податке о храмовима Свете земље, њиховим димензијама, положају, уз обиље детаља о изгледу унутрашњости, приликом чега се набраја број стубова, степеника, прозора, икона, кандила и нојевих јаја. Нарочито је обраћена пажња на присуство мермера уграђеног у храмове уз наглашавање где се налазе, да ли на поду или по зидовима, као и са ближим описом њихових боја и врстом шара ако су их имају. Скоро редовно указује се на удаљеност храмова од Христовог гроба и на њихову величину. Притом су коришћени називи старинских мера који су били уобичајени за ранија времена. Тако се срећу следећи називи: стопа, корак, прст, педаљ, лакат, стол, миља, стадија (Влајинац 1961, 1964, 1968, 1974). Двема последњим мерама исказана је удаљеност до храмова, планина, река, језера и других објеката ван Јерусалима и то рачунато од самог града.

Важнија збивања из библијске историје увек су наглашена кроз краће излагање, понекад у анегдотском облику. Тиме је употпуњена и оживљена представа о личностима које су некада ту постојале. Нарочит значај придавао се чудима која су се одвијала на датим местима. Неретко, навођени су цитати из Светог писма, чиме се снажила изворност изнете садржине у проскинитариону. Иако је остао анониман, састављач овог писаног водича био је веома упућен и богословски образован. Заснован на поузданим упутствима, проскинитарион омогућава врло јасан увид у простор Свете земље.

Проскинитариони су били понекад илустровани представама храмова уз њихове описе. Те илустрације представљају стилизоване приказе храмова насликане бојама у манирима минијатурног сликарства. У грчкој писаној традицији ова појава била је далеко богатија и чешћа него што се то догађало са српским рукописним водичима по Светој земљи. Пре двадесет година у Грчкој се појавила књига Сотириса Кадаса посвећена илустрацијама из проскинитариона XVII и XVIII века, у којој је приказано обиље рукописа те врсте са различитим стилским одређењима (К $\alpha \delta \alpha \varsigma$ 1998). Иначе, код Грка се повремено јављају и штампани проскинитариони почев

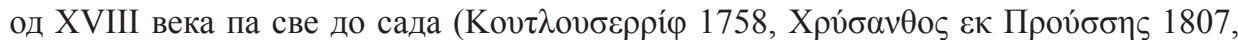
Пробкиvұта́pıov 2017).

Није познато када је проскинитарион преведен код Срба. Свети Сава је током своја два путовања у Свету земљу могао бити упознат са писаним водичем на грчком језику. Да ли је том приликом и донео овај користан приручник и дао га да се преведе на српски, остало је ван наших сазнања. Сачуван је само мали број рукописа које је Свети Сава могао донети из Свете земље, чиме се поткрепљује вероватноћа да се међу њима нашао и проскинитарион (Джурова 2005). Прву сачувану потврду проскинитариона у скраћеном облику на српскословенском језику срећемо 1359/1360. године у такозваном Бдинском зборнику, исписаном старањем царице Ане, супруге бугарског цара Јована Страцимира. У Зборнику се међу шеснаест житија светих жена налази и опис светих места у Јерусалиму, који је у великој мери подударан са проскинитарионом, али у далеко сведенијем облику (Bdinski Zbornik 1972: 234a-2416; Scharpé, Vyncke 1973: 235-242). 
Превод проскинитариона са грчког језика, опет само у деловима, налазимо затим код Константина Филозофа (Petrova 1998: 255-270). Иако је он изгледа превео проскинитарион у целини, данас су нам познати само његови делови. Константин је путовао у Јерусалим између 1415. и 1420. године и као ходочасник највероватније је превео овај спис за време тамошњег боравка (Куев, Петков 1986: 521). Једна од целина која се тиче описа Јерусалима сачувана је у српском препису насталом 1556. године и налази се у зборнику рукописне збирке манастира Никољца са сигнатуром 49 (Станковић 1994: 179-181). Зборник је преписао познати монах Висарион Дебарски (Ангелов 1978: 156-248). На почетку састава нацртан је стилизовани план Јерусалима. У истом зборнику налази се спис под називом $O$ смотрењу васељене, који је такође превео Константин Филозоф. У њему се углавном наводе растојања између појединих земаља, крајева и места. Раздаљине су исказане у старинским мерама монама, то јест предасима (Ангелов 1978: 192-193). Нешто млађи препис О смотрељу васељене од Висарионовог потиче из 1567. године и чува се у збирци Валтазара Богишића број 19с у Цавтату (Богдановић 1982: 106; Novaković 1884: 54-55; Ангелов 1967: 192-193; Петровић 1995: 79-87). Нека лична Константинова запажања, нарочито у Опису Јерусалима, говоре о подешавању превода у којем је околина Јерусалима упоређена са бугарским планинама. Његова надахнутост Јерусалимом показала се посебно у Житију Стефана Лазаревића, у коме су Београд и Стефанова задужбина Манасија упоређени са Јерусалимом.

Као духовник српског манастира Светих арханђела у Јерусалиму, Никон Јерусалимац стекао је велики монашки углед и постао духовник Јелене Балшић. Своју преписку са Јеленом унео је у такозвани Горички зборник, настао 1441/42. године. Уз разноврсне преписе у Зборнику је и једно Никоново изворно дело под називом Повест о јерусалимским ирквама и пустиюским местима (Трифуновић 1972: 289-327). Ово дело прожето је поетским рефлексијама. У појединим деловима оно подсећа на путописе, али још више на проскинитарионе.

Тек у XVII и XVIII веку постоје сачувани целовитији рукописни проскинитариони. Најстарији од њих потиче из 1642/43. године. Препис је начинио, како је записао тајнописом, „грешни поп Тома”. Овај препис описа Јерусалима делимично је сачуван у оквиру Седмичног октоиха, који се данас налази у оквиру збирке Библиотеке Матице српске у Новом Саду са сигнатуром PP I 31. Почетак списа обима отприлике око два листа није сачуван, јер су ти листови истргнути (Кириловић 1979: 53-69; Минеји, октоиси, триоди 1996: 51). Опис Јерусалима попа Томе свакако представља проскинитарион, али је према неким језичким и синтаксичким решењима другачији од осталих познатих српских преписа. Уз то што је окрњен на почетку, он је иначе краћи и сажетији у односу на друге проскинитарионе. За сада се не може утврдити да ли је поп Тома само преписивач овог дела, или је као евентуални поклоник Христовог гроба прибавио овај водич.

Посебну врсту проскинитариона срећемо код Сарајлије Гаврила Тадића. Он је са групом својих суграђана стигао у Јерусалим 1661. године и о свом доласку оставио запис у једном рукопису. О Гаврилу Тадићу зна се да потиче из угледне сарајевске породице Хумковић (Скарић 1928). Док је боравио у Јерусалиму, Гаврило је исписао поклоник по светим местима. Његов препис илустрован је представама важнијих храмова и данас је делимично сачуван, тако да се у њему налазе 34 
минијатуре у боји. Спис се налази у српском рукопису Народне и Универзитетске библиотеке у Јерусалиму под сигнатуром Ms. Var. 186 и познат нам је у издању Маре Харисијадис (Тадић 1986: 113-132). У основи, ово дело је проскинитарион са личним запажањима о светим местима. Састав је исписан српскословенским језиком са одликама народног језика.

Непознати писар XVII века оставио је попис конака од Јерусалима до Синајске горе. Данас је тај спис у рукопису старе збирке Архива Српске академије наука и уметности са сигнатуром 46. По обиму и по типу сличан водич постојао је већ у преводу Константина Филозофа. Ипак, места на која се односе раздаљине у њима различита су. Иако је у наслову означено да састав говори о конацима између појединих места, у њему је много више објашњења и указивања где се који храм налази или шта се где од библијских збивања одиграло. Понеки турцизам или арабизам говори о уласку туђих речи преко народног говора у стари српски књижевни језик. Извесна сликовита места у излагању чине овај састав литерарно богатијим него што би представљало обично набрајање конака (Новаковић 1869: 32-33).

У изгорелој збирци Народне библиотеке Србије налазио се један илустровани водич по светим местима с краја XVII или почетка XVIII века са сигнатуром 916 (Матић 1952: 164; Стояновичъ 1886: 1-27). Састав је по типу скоро истоветан путопису Гаврила Тадића. Преписала га је нама непозната особа. Оба проскинитариона су илустрована и највероватније су потицали од истог предлошка који је тада био у Јерусалиму по казивању Гаврила Тадића.

Живоносном Гробу поклонио се током 1729. године Јован Дамјановић из Будима (Перић 1983: 67-84; Перић Стефановић 2004: 13-20) и о томе оставио запис као и препис једног водича по Светој земљи из 1766. године, који се данас чува у Музеју Српске православне цркве под сигнатуром 349 (Павић 1970: 504). Јованов проскинитарион има композицију сличну Опису Јерусалима Христофора Жефаровића и постоји могућност да је тај спис користио преписујући га у великој мери. Жефарофићев Опис појавио се из штампе 1748. године, што је Дамјановић по свој прилици искористио и из њега преузео делове из увода и још неких других целина. У појединим деловима водич Јована Дамјановића опширнији је од Жефаровићевог, али се налазе и обрнути примери. Дамјановићев водич показује и неке личне утиске о виђеном, што указује да то није био само пуки преписивач. Спомињући сусрет са једним Бошњаком, проговорио је и о неким приликама у Јерусалиму:

„Ко хоће све да прегледа, онда треба да се споразуме и распита код Турака који су тамо на стражи и они ће показати све. Само треба да им се плати по једна пара. У време када ја бејах тамо, беше један Турчин Бошњак, из Босне. Испитавши нас одакле смо, погости нас кафом.” (Света земљьа 2007, 207).

Није изоставио једно лоше искуство са турским властима у Јерусалиму:

„У тим палатама мене, хаџи Јована Дамјановића, рођеног у престоном граду Будиму, држаше паша у затвору два сата због харача. А имао сам пасош из Беча цара Карола и пасош будимског генерала Јунгтаона. А Арапи Турци, упркос томе, кажу: ,Ми у овдашњим земљама налазимо се у нужди и оскудици, и ако би и сам наш цар дошао овде из Цариграда, ми бисмо га опљачкали. “ И дође од патријарха Хрисанта епитроп Мелентије и измоливши ме, ослободи ме.” (Света земља 2007: 211). 
У ређање појединих раздаљина у Јерусалиму унео је и сопствено искуство: „И та врата су широка 31 стопу, како их ја грешни измерих" (Света земља 2007: 206). „Црква је веома красна, дуга и широка 44 стопе. Ја грешни Јован мерих” (Света земља 2007: 211-212). Његово излагање тиме је знатно оживљено. Јованов сусрет са птицом нојем, слично је као у путопису Јеротеја Рачанина: „И ту видех птицу ноја, која једе железо и олово. И висока је колико магаре. Ноге јој као у магарета, шија и глава као у лабуда, реп као у ждрала" (Света земља 2007: 209). У личном тону исписана је и завршна реченица Дамјановићевог водича. У њој као да се осећа његова спреченост да препише и преостале делове пошто је до окончања дошло нагло и без природнијег привођења крају: „Многа су места у Јерусалиму, али само мали део описасмо" (Света земља 2007: 212).

Од проскинитариона који су имали велику улогу код српских читалаца посебно место заузима Описаније Јерусалима, које је Христофор Жефаровић штампао као књигу 1748. године (Жефаровић 1973). Типографским изгледом, са бројним илустрацијама које је Жефаровић резао у бакарним плочама, Описаније је у свом времену, по оцени познавалаца тог периода српске прошлости, представљало прави издавачки подухват. Та књига настала је пре свега из потребе да се српским читаоцима приближе света места и подстакну будући ходочасници на свој поклонички пут. Она се појавила залагањем јерусалимског архимандрита Симеона Симеоновића, који је Жефаровићу предао за штампу рукопис са илустрацијама. Одобрење за штампање дао је митрополит Арсеније Антоновић. Од будућих читалаца архимандрит Симеон очекивао је помоћ и путем слања новца макар да се и не буде у могућности да се физички посети Свети град. Жефаровићев Опис Јерусалима доживео је и своје друго издање 1781. године, у чему се огледала знатна потреба за оваквом књигом. Његове илустрације послужиле су како за српско тако и за грчко издање проскинитариона, као и на још неким језицима (Ковачевић 1954: 17-22). Језик којим је писана Жефаровићева књига јесте рускословенски са елементима српскословенског и српског народног.

Поред Јована Дамјановића, који је користио Жефаровићев Опис Јерусалима, уносећи делове у свој препис проскинитариона, са великом поузданошћу могло би се говорити да је нама непознати преписивач завршио преписивање ове књиге 14. фебруара 1763. године. Његов препис сада се налази у Архиву САНУ под бројем 31. Неки делови преписа не подударају се сасвим у редоследу излагања са Жефаровићевим Описом. Нити цео предговор као ни поговор овде нису у целини пренети. Знајући за овакву појаву, није немогуће да је било још таквих случајева преписа Жефаровићевог штампаног проскинитариона. Уосталом, то није усамљена појава да се штампане књиге преписују, поготову током XVIII века (Бојовић 2017: 9-17).

Српски проскинитарион до сада није обухватније проучен. Предстоји издање свих сачуваних текстова како би се утврдила њихова распрострањеност, текстолошки увид, варијантност и веза са грчким изворима. И без тога стиче се представа о проскинитариону као непрестано присутном водичу код Срба током векова у којима се одлазило у Свету земљу и настојало да се она уз непосредан доживљај упозна и преко разрађених упутстава и обавештења која је овај писани приручник пружао. Попут чудесне књиге, овај водич поуздано је разоткривао света места и дочаравао њихов изглед обиљем података о бројним храмова. Поклоници који би стизали у 
Свету земљу и који су настојали да у писаном облику проговоре о свом доживљају са тог пута, и притом имајући прилику да користе проскинитарион како би сазнајно употпунили виђено, свакако су били под утисцима које им је оставила његова богата садржина. Неки од њих прибегавали су споју већ затеченог текста проскинитариона са макар и оскудним уношењем у њих свог доживљаја Свете земље и у том облику их исписивали сматрајући их личним поклоничким трагом. У томе су се нарочито истакли Константин Филозоф, Никон Јерусалимац, поп Тома, Гаврило Тадић и Јован Дамјановић. Њихове реченице у којима се препознају лични утисци лако су приањале уз проскинитарионска указивања на изглед храмова и на њихове раздаљине. У спојевима тако обликованих састава нема одлика правог путописа у коме се осећа динамика кретања, већ се одликују низањем података и дочаравањем спољашњости и унутрашњости цркава. Ипак, њихова дела, макар у малом, говоре о личном присуству на широким просторима Свете земље. Она су истовремено сведочења о надахнутости поклоника тако важним простором.

У старој српској књижевности постоје дела која су прожета вишеструким искуством и доживљајима на путовању и боравком у Светој земљи. Од свега што се сачувало од тих дела, тек нека остала су целовита. Већ најстарија позната посланица Светог Саве упућена из Свете земље студеничком игуману Спиридону позната нам је у препису (Daničić 1872: 230-231), који је највероватније спој две засебне целине (Јанковић 1990: 186-188). У њој је Сава саопштио језгровито и делимично на поетски начин своје утиске о боравку у Светој земљи.

Далеко целовитије и обухватније Доментијан је описао Савино путовање и боравак у Светој земљи у Житију Светог Саве. Потпуно у маниру путописног жанра дочарао је сложен и догађајима испуњен Савин поклонички подухват. Његово сведочење је утолико драгоценије и доживљено јер је Саву пратио на једном од два путовања и свакако унео неке личне утиске. Заснивајући своје Житије Светог Саве на Доментијановом делу, Теодосије је такође обликовао две путописне целине о Савиним путовањима у Свету земљу. Обојица су изразито наративно пропратили Савина путовања и кретање по просторима Свете земље.

Хиландарски игуман Лаврентије путовао је са Свете Горе у Јерусалим највероватније у трећој деценији XVII века и о томе оставио путопис. Сачували су се само остаци његовог дела у препису Јеротеја Рачанина из 1698. године (Кациба 1994: 50-67; Јовановић 1994: 95-108). Тај препис данас се налази у рукописној збирци Радослава Грујића у Музеју Српске православне цркве у Београду под бројем 3-II-9. Неки делови Лаврентијевог путописа већ тада су били изгубљени, тако да их је Јеротеј преписао у окрњеном облику. Лаврентије се умногоме угледао на писани проскинитарион набрајајући места кроз која је пролазило не описујући их ближе. Њега су нарочито занимале поједине библијске легенде и личности као и места из хришћанске историје.

Кратовски митрополит Михаило био је једно време у служби српског патријарха Пајсеја. Пошавши из Москве и преко Свете Горе, допутовао је у Јерусалим 1657. године. Опширније писани извештај о повратку из Свете земље оставио је руском царинском чиновнику у Путивљу. То његово казивање, иако сачувано тек из друге руке, представља драматичан и неизвестан Михаилов пут до Јерусалима, али ништа мање занимљив и на повратку. Саопштење је испуњено личним утисцима током 
читавог путовања. У Јерусалиму га је посебно занимало да сазна нешто више о јављању светог пламена, од кога се пале свеће свих окупљених, али није му било допуштено да уђе у храм Христовог гроба иако је подмитио Турчина који је чувао улаз. Знатан део казивања посветио је боравку у Цариграду и убиству цариградског патријарха Партенија као и интригама које су претходиле том догађају. Док је боравио у Цариграду, митрополит Михаило је срео угледне Србе, код којих се распитивао за патријарха Гаврила. Из Цариграда отишао је у Свету Гору, одакле је преко српских крајева, Молдавије и Пољске стигао у Путиваљ, где је царинским властима дао извештај о свом поклоничком путу.

Патријарх Арсеније Црнојевић путовао је у Свету земљу из Пећи до Јерусалима и назад током 1682-1683. године и то описао у облику путописа. То његово дело није сачувано у аутографу, него у једном непотпуном препису, који се данас налази у Архиву САНУ под сигнатуром 328. Велики део преписа у коме се говори о доласку у Свету земљу и повратку у Србију изгубљен је. Сликовити су и надахнути његови описи проласка кроз разна места од Пећи ка Цариграду, као и сусрети са бројним успутним личностима и својим пратиоцима. Места која су на путу постајала све ближа мору и Цариграду као да су још више опчињавала патријарха својом лепотом. Он се одушевљавао великим и лепим мостовима, уређеним хановима, шедрванима, царским палатама, вртовима, сарајима, џамији и имаретима Мехмед паше Соколовића и приморском граду Силиврији. Макар и оволико оскудан одломак Арсенијевог путописа открива пишчеву осећајност и даровитост исказану у жанру негованом код Срба још од времена Светог Саве.

Јеромонах Јеротеј Рачанин стигао је у Јерусалим 1705. године и о свом путовању оставио опширан путопис, који представља прво целовито сачувано дело тог жанра. Своја сећања на путовање у Света места написао је тек 1727. године у фрушкогорском манастиру Ремети. Аутограф путописа није сачуван, али га је пре пропасти објавио Осип Бођански (Бодянскій 1861: 1-42) и неке делове Стојан Новаковић (Новаковић 1871: 294-295). Јеротејево путовање од Београда долином Мораве и Вардара све до Солуна обележено је навођењем редоследа конака. Слично је учинио и са дочаравањем боравка у Египту, Синају, Јерусалиму и његовој ближиј и даљој околини са снажном доживљеношћу виђеног. Лични тон присутан је кроз цео путопис са живим сликама и сусретима са бројним особама. Упечатљив је његов сусрет са нојем у Египту: „И ту видех птицу ноја. Големо. Једва дохватим руком по хрпту. И миловах га. Ходају по чаршији и поред лађа, по буњишту. Купе штогод те се хране.” Узбудљива су посебно два описа буре на Егејском мору и сусрет са гусарима. Посматрачко умеће испољио је описујући ускршње богослужење у Великој цркви на Христовом гробу са обиљем литургијских података. Успут је бележио легенде које је сазнавао успут.

У много скромнијем облику, али са снажним личним утисцима, написан је путопис Силвестра Поповића, који је боравио у Јерусалиму током 1745/46. године. У виду дневника записивао је утиске са свог поклоничког путовања. Његов рукопис био је у старој збирци Народне библиотеке Србије са сигнатуром 1017 и страдао је 6. априла 1941. године у немачком бомбардовању Београда. Овај путопис обележен је живахним гледањем на појаве које је Силвестар сретао у далеком свету. Његове асоцијације и запажања поводом успутних збивања испуњена су ведрином каква 
се не среће у старијим делима овог жанра. Када је присуствовао богослужењу у великој цркви у Солуну, запазио је неуједначеност у опхођењу свештеника. Неке од њих окарактерисао је локалном изреком поредећи их са покретима воденичара Милашина: „Господин архиепископ доста обично и уредно служи, а други се мету по цркви као Милашин по воденици". Завичајну боју унео је у излагање и када стигао под град Сидон, испод кога турски војници „цео дан протркују коње прудом покрај мора, од града до логора и од логора до града, као пијани Цигани с футошког вашара". Сличних места у његовом путопису има још и она откривају сву свежину приступа виђеном.

Андреј Петковић путовао је у Свету земљу 1734. године. Био је пратилац имућном човеку по имену Ћира, који га је примио „као отац сина”. За узврат, Андреј му је обећао да ће му на путу служити „у свакој потреби”. Андреј није навео одакле је био, него само да су од свог места до Београда имали шест конака. У путопису је присутан снажнији продор народног језика са локализмима који обележавају војвођанске говоре. Дело није сачувано у целини. Недостају делови који говоре о периоду после искрцавања у Јафи и описи појединих светих места око Јерусалима, као и о повратку. Оно што Андрејев путопис чини посебним јесу илустрације које прате важнија места у Светој земљи. Сачувана је 21 минијатура у боји, а свакако их је било више у целовитом путопису. Дело је објавио Стеван Бугарски у Темишвару паралелно на српском и румунском језику и изнео претпоставку да би Андреј био „Војвођанин, можда и Банаћанин” (Петковић 2008).

Из банатског места Баваништа допутовао је 1781. године у Јерусалим Павле Стојановић. Његов пут водио је преко Трста, Јадранског и Средоземног мора. Из Јерусалима је упутио два писма. Једно је послао брату Петру, а друго својој родбини пред полазак из Јерусалима. На повратку је свратио у Хиландар. Поред ова два писма у посебној бележници исписивао је путописна запажања са путовања. Сва три састава објавио је Илија Берић 1843. године у три наставка у Српском народном листу (Берић 1843, 7, 54-56; 8, 63-64; 9, 70-72). Објављујући ове саставе, Берић је задржао њихов језик какав је затекао у аутографима и штампао их је предвуковским правописом. Сва три дела писана су народним језиком у коме се снажно осећа банатска говорна боја. Тек понека реч потиче из књижевног језика са руским фонетским одликама. Његова писма и белешке одликују се лирским тоновима и усхићењем што му се пружила прилика да дође на поклоњење Христовом гробу.

„Састави везани за путовање у Свету земљу, писани на српскословенском, рускоцрквенословенском и српском народном језику, допринели су на посебан начин мотивској разнородности и укупном обогаћењу српске књижевности. Својом поетском заснованошћу ова дела дубоко су окренута обрасцима старе књижевности. Њихово настајање током низа векова говори о сталности путовања Срба у Свету земљу, као и о изузетној постојаности овакве теме на којој су се, почевши од светога Саве, опробали бројни писци" (Света земља 2007: 38-39).

\section{Лuтература}

Ангелов Б. С. Из старата българска, руска и сръбска литература II. София, 1967. Ангелов Б. Из старата българска, руска и сръбска литература III. София, 1978. 
Берићь, И. „Описаніе града Ерусалима, кое е бывшый житель Баванишкый Павель Хаџи Стояновићь у 1781 години рож. Хрістова приликомъ поклоненія своега къ светоме гробу спасителЂвомъ самъ описао." Сербскій народный листъ, VIII, 7, 18. фevpyapia $1843 ; 8,25$. фevpyapia; 9, 4. марта.

Богдановић Д. Инвентар ћирилских рукописа у Југославији (XI-XVII века). Београд: САНУ, 1982.

Бодянскій О. Путьшаствіе къ граду Іерусалиму Іеровея Рачанинскаго, въ льто отъ бытія 7212, а отъ Рож. Христова 1704, мъсяиа Іюліа 7. Чтенія къ Императорскомъ обществъ исторіи и древностей россійскихъ при Московскомъ университетъ, кн. IV, октябрь - декябрь, Москва 1861. Поновљено у: Маринковић Б. „Одломци трагања за Рачанима и традицијом о Јеротеју Рачанину.” Годишњак Филозофског факултета у Новом Саду, XII/I (1969): 263-300. Најновије издање у: Димитрије Кантакузин, Константин Михаиловић из Островище, Пајсије, Арсеније ІІІ Црнојевић. Антологијска едиција Десет векова српске књижевности, књ. 4. Приредио Томислав Јовановић. Нови Сад: Издавачки центар Матице српске, 2018.

Бојовић 3. „Преписи штампаних књига у српској средњовековној традицији.” Средњи век у српској науичи, историји, књижевности и уметности, VIII. Дани српскога духовног преображења, XXIV. Деспотовац, 2017.

Влајинац М. Речник наших старих мера у току векова I-IV. Београд: САНУ, 1961-1974.

Джурова А. „Какво е донесъл патриарх Сава Сръбски от Ерусалим?” България и Сърбия в контекста на византийската цивилизачия. София, 2005.

Жефаровић Х. Описаније Светаго Божија града Јерусалима, В Виене, 1748го новембрија 30. Појавила су се још два издања у Бечу: 1772 и 1781. Нови Сад, 1973.

Јанковић, Ж. „Око Посланице игуману Спиридону.” Гласник, Службени лист СПЦ, LXXI, 9 (1990).

Јовановић Т. „Лаврентијев путопис.” Књижевна историја, XXVI, 92 (1994).

Кациба А. „Лаврентијево путовање из Хиландара у Јерусалим у препису Јеротеја Рачанина.” Biblioteca Slavica Savariensis, II (1994).

Кириловић Д. „Һирилске рукописне књиге у Библиотеци Матице српске.” Годишьак Библиотеке Матице српске за годину 1977, II (1979).

Ковачевић Б. „Неколико прилога библиографији. I - Стари српски вођ кроз Јерусалим. Кад је изишло прво издање „Описанија Јерусалима?” Библиотекар, 6/1 (1954).

Куев, К., Петков, Г. Събрани съчинения на Константин Костенечки. София: Изследване и текст, 1986.

Матић С. Опис рукописа Народне библиотеке. Београд 1952.

Минеји, октоиси, триоди. Ћирилске рукописне књиге Библиотеке Матице српске. Књига V. Нови Сад, 1996.

Новаковић С. „Прилози к историји српске књижевности. Један стари свјетовни зборник ћириловски.”, Гласник СУД, VIII, XXV свеска старога реда (1869).

Новаковић С. „Прилози к историји српске књижевности. VI Јеротија Рачанина пут у Јерусалим 1704. год." Гласник СУД, ХXXI (1871).

Павић М. Историја српске књижевности барокног доба (XVII и XVIII век). Београд: Нолит, 1970. 
Перић Ђ. „Прилози биографији монаха Исидора (Јована Дамјановића), непознатог српског песника и путописца из XVIII века." Православна мисао, 30 (1983).

Перић Ђ., Стефановић Д. „Нешто о животу и списима јеромонаха Исидора Дамјановића (1696-1764).” Рачански зборник, 8/9 (2004).

Петковић А. Поклоњење гробу Господњем 1734. Incinare la mormântul Doтnului. Приредио Стеван Бугарски. Ediție îngrijitå de Stevan Bugarski. Темишвар: Савез Срба у Румунији - Timişoara: Uniunea Sârbilor din România, 2008.

Петровић Д. „Константин Философ као путописац.” Љубомир Ненадовић и српска путописна традищија. Приштина 1995.

Света земља у српској књижевности од ХIII до краја XVIII века. Приредио и на савремени српски пренео Томислав Јовановић. Београд: Чигоја штампа, 2007.

Скарић В. Српски православни народ и ирква у Сарајеву. Сарајево, 1928.

Станковић Р. „Датирање и водени знаци рукописних књига манастира Никољца.” Археографски прилози, 16 (1994).

Стояновичъ Л. В. „Сербское описаніе святыхъ местъ первой половины XVII века.” Православный палестинскій сборникъ, V, Вып. 2. С. Петербургъ, 1886.

Тадић Г. „Поклоњеније Частного гроба и Светих мест ва светом граде Јерусалиме. Повест нека избрана.” Приредила Мара Харисијадис. Кьижсевна историја, XIX (1986): 73-74.

Трифуновић Ђ. „Две посланице Јелене Балшић и Никонова Повест о јерусалимским црквама и пустињским местима." Кюижевна историја, V, 18 (1972).

Трифуновић Ђ. Азбучник српских средњовековних књижевних појмова. Друго, допуњено издање. Београд: Нолит, 1990.

Bdinski Zbornik. Ghent Slavonic Ms 408, A. D. 1360. Facsimile edition with a presentation by Ivan Dujčev. London, 1972.

Daničić, G. „Poslanica sv. Save arhiepiskopa srpskoga iz Jerusalima u Studenicu igumnu Spiridonu." Starine JAZU, IV (1872).

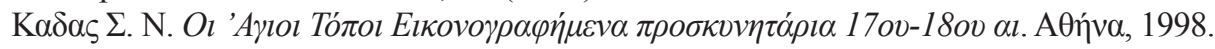

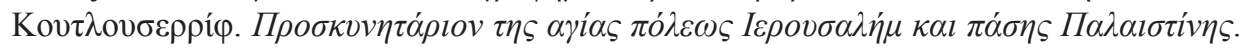

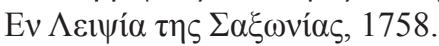

Novaković S. „Odlomci srednjevjekovne kosmografije i geografije.” Starine JAZU, XVI (1884).

Petrova M. „An Unknown Copy of the Description of Jerusalem by Constantine of Kostenec." Byzantinoslavica, LIX (1998).

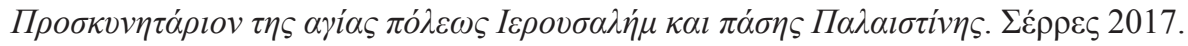

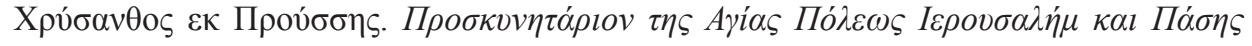

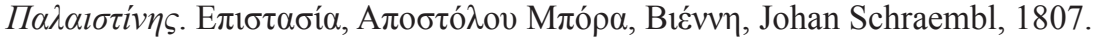

Scharpé J. L., Vyncke F. Bdinski Zbornik. An Old Slavonic Menelogium of Women Saints. Critical Edition. Brügge, 1973. 
Томислав Ж. Йованович

ПРОСКИНИТАРИЙ И СЕРБСКАЯ ПУТЕВАЯ ПРОЗА, ПОСВЯЩЕННАЯ

СВЯТОЙ ЗЕМЛЕ

Резюме

Путеводители по Святой земле, или проскинитарии, на всем протяжении средних веков, вплоть до новейшего времени, являлись важными и необходимыми указаниями для путешественников, направлявшихся в те края, и прежде всего, на поклонение Гробу Господнем. Содержавшиеся в них подробные описания храмов с окрестностями вокруг Гроба Господня служили паломникам для лучшего ориентирования по прибытии в святые места. Своей исчерпываемостью они оставили глубокий след в произведениях путевой литературы сербских паломников, особенно в произведениях, описывающих Святую землю. Сохранились и некоторые выраженно путевые произведения в древней сербской литературе. Они отличаются личным переживанием и повествовательной динамикой, сопровождающей жанр путешествия.

Ключевые слова: проскинитарий, Святая земля, сербская путевая литература. 